\title{
Sustainability Concerns of Smallholder Irrigation Schemes in the Bawku Municipality of Ghana
}

\author{
Jonas Ayaribilla Akudugu \\ Center for Development Research, University of Bonn, Germany \\ Walter-Flex-Str. 3, 53113 Bonn, Germany \\ Tel: 49-152-1663-0892_E-mail: akujonaya@yahoo.com
}

Received: March 22, 2013 Accepted: April 15, 2013

doi:10.5296/emsd.v2i1.3416 URL: http://dx.doi.org/10.5296/emsd.v2i1.3416

\begin{abstract}
Irrigation development has become an important intervention to the people of Northern Ghana where rain-fed agriculture is no longer yielding the desire results. In view of the high degree of rainfall variability and unreliability, the development of irrigation creates opportunity for the people of this part of the country to cultivate at least vegetables during the long dry season. In line with this, the Government of Ghana with the support of the International Fund for Agricultural Development (IFAD) rehabilitated a number of broken down Smallholder Irrigation Schemes in the Upper East Region in the early 1990s under the Upper East Region Land Conservation and Smallholder Rehabilitation Project (LACOSREP). In an attempt to promote community ownership and sustainable management of these schemes, the Water Users Associations were formed in each community to manage them. However, with the passage of time, it is becoming clear that the sustainability of these Smallholder Irrigation Schemes goes beyond the formation of Water Users Associations at the community level. Focusing on the Binduri Irrigation Scheme as a case study, this paper highlights the "taken-for-granted" issues or factors that threaten the sustainability of these Smallholder Irrigation Schemes.
\end{abstract}

Keywords: Irrigation, Infrastructure, Institutions, Management, Sustainability

\section{Introduction}

Irrigation development in the Northern Savannah belt of Ghana can be traced to the early 1960s when the State actively intervened to modernise agriculture in the country. Seini (2002) notes that the post-independence period (1957 - 1966) was an era of massive state participation in agriculture, during which attempts were made to develop large scale farming 
through mechanised agriculture. The construction of irrigation schemes in the Northern Savannah belt of Ghana was aimed at helping to boast agricultural production in the area, which experiences lesser rainfall in the country. Irrigation has since played an important role in the socio-economic life of the people in this part of the country. Small-scale irrigation schemes in particular now constitute a primary source of livelihood to many rural households that have access to them. As Ramagundan (2009: 17) notes "building irrigation infrastructure helps to generate wealth for those who have land". The development of irrigation for dry season gardening has now been seen as the best way forward for increasing food production and improving rural household incomes,(Akudugu, 2008). In the early 1990s, the Government of Ghana in partnership with the International Fund for Agricultural Development (IFAD) rehabilitated a couple of small-scale irrigation schemes and handed them to the local communities to manage. One of such schemes is the Binduri Irrigation Scheme, which was constructed in 1960 and rehabilitated in 1994/1995.

Irrigation schemes in Ghana (both large and small) have been under State control and management until the late 1980s. Following the introduction of neo-liberal economic policies into the country, the State gradually shifted the management of small-scale irrigation schemes to local communities. Community ownership and management was conceived as the best approach for ensuring the effective use and sustainability of the small-scale irrigation schemes. "Water supply schemes with high citizen participation are more effectively and efficiently maintained and managed than those with little or no citizen participation [...] thus, efforts to transfer control over water supply schemes from national corporations to local communities reduce the ineffectiveness and other problems concomitant with highly bureaucratic institutions" (Njoh, 2011: 377). Community management of Small-scale Irrigation Schemes was thus advocated as a means of ensuring community participation, but more importantly as a means of ensuring their sustainable use.

However, as the years go by, it appears the sustainability of these small-scale schemes cannot easily be guaranteed by merely transferring their management to local communities. Although smallholder irrigation schemes have become critical economic assets, their sustainable management has become a matter of concern. While people in the communities are happy to have access to irrigation facilities for dry season gardening, the use of these facilities and their general management raises issues regarding their sustainability. For instance, "the increasing transfer of water infrastructure from governments to farmers or irrigation districts raises questions about future sources of financing" (Simon, 2002; cited in Ward, 2010: 322). These concerns have in turn led to calls for the reversal of community water resources back to state management. "Although there is greater acceptance that farmers can manage their irrigation systems efficiently, many irrigation experts believe that a shift from informal to more formal management strategies will lead to even better water-flow management" (Lorenzen and Lorenzen, 2008: 77). As Shepherd (1998) notes, for common pool resources to be managed sustainably in environmental and equity terms, the rules may need to change. It is in view of this that Gareth (2004) argues that "governments must accept a major share of responsibility in establishing a framework within which a sustainable water resources management policy must operate, for it is mainly through government policy that the attitude of the general public can be modified to accept that a greater efficiency in the 
appropriate use and conservation of water is necessary". Sustainability calls for better resource management, (Haughton and Counsell, 2004). But it appears the concern of the people is on access and use of the irrigation schemes rather than addressing questions of sustainability. This paper examines the interplay of factors that threatens or affects the sustainability and long term viability of the Binduri Small-scale Irrigation Scheme in the Upper East Region of Ghana.

\subsection{Methods}

The data for this paper were obtained through questionnaire administration; focus group discussion, observation and mapping. Three focus group discussions were held with the water users, operating at different locations within the scheme. Number of participants per each focus group discussion ranged from nine (9) to twelve (12) water users. The researcher also observed dry season farming activities at the dam's catchment area and activities carried out so far around the dam aimed at protecting the dam. Activities at the irrigable area were also observed. Mapping was another technique used to collect data for this exercise. The catchment area of the dam was mapped for analysis. Trend line analysis was also employed. This tool was also used to collect and analyse time-related data. It was used to collect and analyse data that depict observed changes in the community over time. The trend line analysis focused on fluctuations in rainfall values recorded in the community over time, changes in population as well as changes in the irrigable area of the dam. The analysis in this paper is largely qualitative in nature.

\section{Results and Discussion}

This section examines the various factors that influence or affect the level of water collected in the Binduri Community Dam and/or the usage of the water, and implications for the sustainability of the scheme.

\subsection{Resource Perception, Institutions and Sustainability}

Natural resources, including water resources are held under different property regimes, such as state, private or common property. The sustainable exploitation of water resources, like the use of the Binduri community dam for dry season gardening and other purposes is largely determined by the property institutions that govern them. It is the institution that defines the user group and determines how the use of a given resource stream like the Binduri irrigation dam is regulated. As Woodhouse et al (2000) note, a complex web of institutions 'customary', induced community organisations, local state, national state and private sector, are involved in determining who has access to the area's resources, how they are utilised and how use is coordinated and regulated or not. In resource management, what is particularly important is the ability of a social group to define and enforce rules regulating access and use of a community resource at any point in time (see Ostrom, 1990). This is achieved largely by the effectiveness of the institutional arrangement in place to define access, exclude non-users and regulate the use of the resource. In other words, the sustainability of a particular resource stream largely depends on the effectiveness of the property institution to define access and regulate the use of the resource stream. While it has often been easy for people to subtract 


\section{Macrothink}

from a particular resource stream, it has in most cases been difficult to enforce the rule of exclusion. As Ostrom (1990) points out, it is costly and in some cases not feasible to exclude one appropriator of a resource system from improvements made to the resource system itself. When existing property regimes or institutional arrangements are unable to regulate access and use of a given resource stream, it exposes it to over-use or exploitation.

One threat to the sustainable use of the Binduri community irrigation scheme is the widespread perception that the dam is a common property or open access resource that must be available to everybody in the community. A survey on the peoples' perception on ownership indicates a seemingly different but the same form of ownership of the dam. As shown in Figure 1,54\% of the respondents were of the view that the dam was constructed by the government, hence it belongs to the government. Similarly, 29\% of the respondents as shown in Figure 1 hold the view that the dam is a property of the community, while $17 \%$ of the respondents think that the dam belongs to the chief of Binduri.

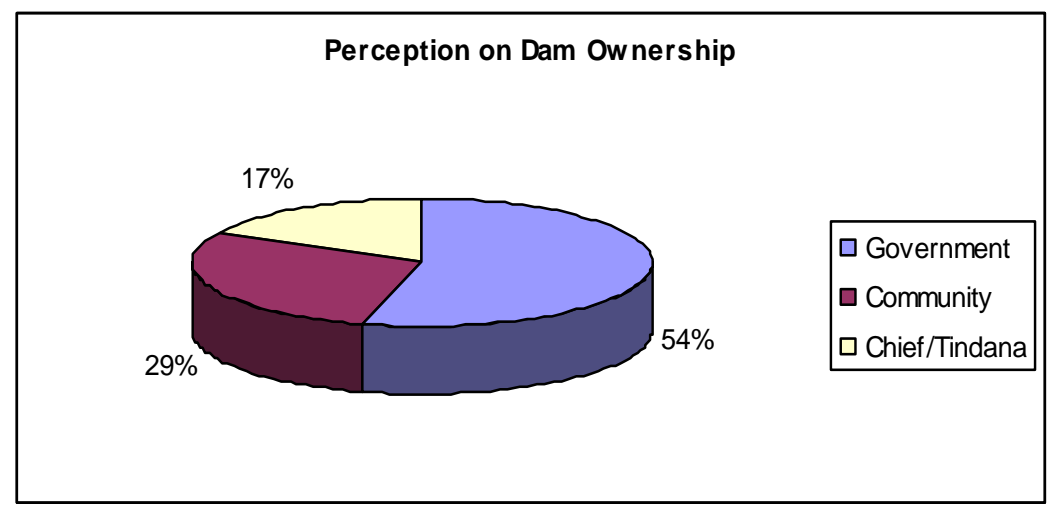

Figure 1. Perception on Dam Ownership

Source: Field Survey

The underlying point in the three views expressed in Figure 1 is that the dam is to be available to all. To them, anything belonging to the government, community or the chief is devoid of individual monopoly and is to be available to all. In the view of all the three groups of respondents, resources under the control of the government, community, and the chief are commonly owned and remain free to everyone in that geographically or socially defined set up.

This represents the first threat to sustainable use and management of the resource. As Gareth (2004) notes, public attitudes towards fresh water resources at the start of the 1990s showed that the majority of people in France viewed water as a freely available, unlimited resource. The perception of the people on the ownership of the resource is linked to the question of access and usage. For instance, most people in the Binduri Community feel they should have unrestricted access to the irrigable land for onion production irrespective of the amount of water in the dam in that particular time period. This thinking and attitude has implications for the utilisation and sustainability of the dam. Its places pressure on the dam and the irrigation infrastructure, especially in the case where the Water Users Association has not been able to 
strictly enforce rules and regulations regarding the use of the scheme (see Akudugu, 2008). The struggle for access and the nature of the use of the resource stream are critical determinants of its sustainability. Where there is an incidence of over use, sustainability if threatened. The Binduri dam can be said to be in a state of over use. It was disclosed that the dam is currently unable to support vegetables farming for the entire dry season.

\subsection{Unfavourable Climatic Conditions}

Climate and the general environment of an area influence almost every aspect of human activity and most of the resources used by man. In terms of irrigation development, rainfall is a vital climatic variable in its existence or sustenance. Rainfall remains the single most important climatic factor that influences the availability and changing use of water in the Binduri community. But as Ostrom (1990) notes, most resource settings, including irrigation systems face uncertain and complex environments. My interviews with the irrigation farmers in Binduri revealed that water in the dam has never been enough for their dry season farming. As Portney (1982) points out, most water needs are time and location specific and they do not necessarily coincide with natural supply availability. The rainfall pattern in the Binduri area is not only relatively low; it is also characterised by a high level of variability. Gareth (2004) notes that in the arid and semi-arid areas of the world, annual precipitation is usually very variable and provides less than what is needed for meaningful crop production. This observation also holds true for the Binduri area which comes under the influence of the interior continental climatic condition. As shown in Figure 2, the data indicate that the highest annual rainfall value recorded in Binduri between1997-2005 was in 1999 (1319.0 mm), while the lowest value was recorded in $2001(753.2 \mathrm{~mm})$. The 1999 rainfall value represents the highest recorded in the community in over 30 years.

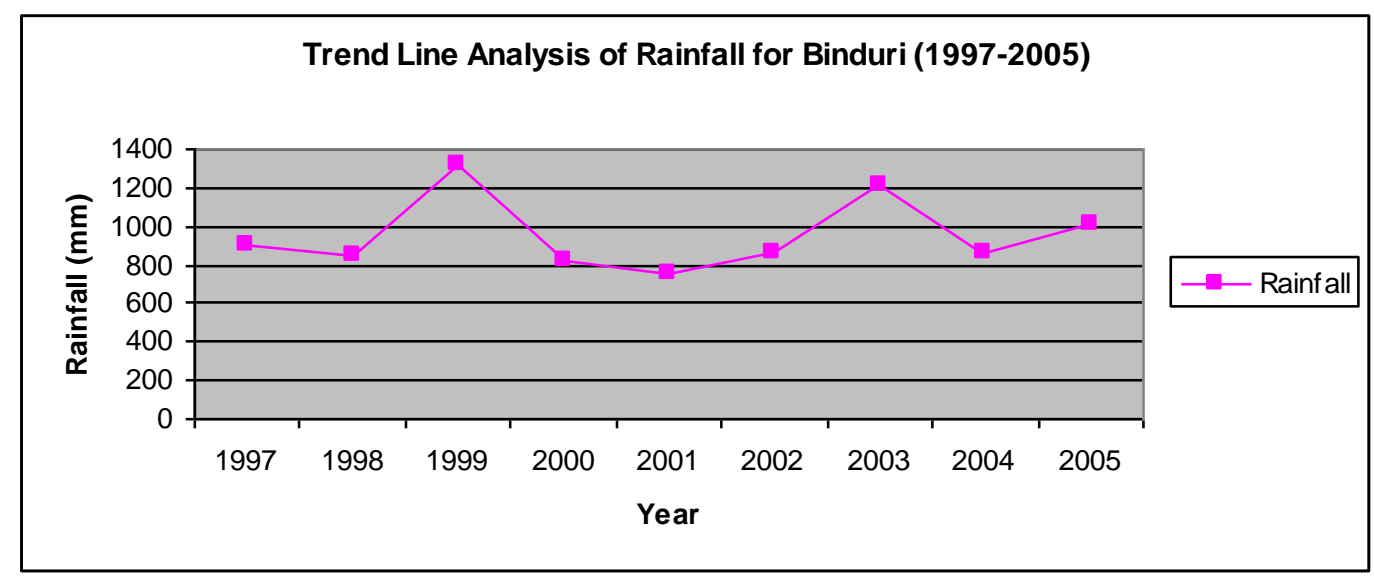

Figure 2. Rainfall Trend Lines (1997-2005)

\section{Source: Meteorological Service Rainfall Records}

The rainfall trends in the community influence both the amount of water collected in the dam and the utilisation of the water collected in the dam. It has been observed that the amount of rainfall that the community records in any particular year has a direct bearing on the amount of water collected in the dam. The low level of water in many water bodies in Ghana is accounted for by the "reduced mean precipitations" (Gyampoh, et al, 2008: 417). As such, 
times of high rainfall in the community also translate into high amount of water in the community dam. But the dam in demand terms is really small yet; a large volume of water is needed to supplement rain-fed agriculture which continues to produce disappointing results in terms of crop yield. Given the small size nature of the dam, periods of low rainfall will further put pressure on the dam since farmers will insist having access to the water for their dry season gardening.

Reduced rainfall or poor rainfall pattern negatively affects rain-fed agriculture which is the main source of livelihood to the majority of Ghanaians, (Gyampoh, et al, 2008). In response to the food shortages during the long dry season, many people and households explore a wide range of coping mechanisms. Households and individuals in the community continue to diversify their coping mechanisms beyond what is obtained from rain-fed agriculture to guarantee themselves some amount of livelihood security at such difficult times. As Bromley (1992) notes, poverty, together with a dependence on low value-added outputs and relatively randomly distributed natural resources results in a high degree of uncertainty with respect to income streams. This scenario depicts the situation in the Binduri community. This uncertainty compels the people to diversify their sources of livelihood beyond rain-fed agriculture. Among the various coping mechanisms that the people often rely on is vegetables produced from dry season irrigation farming. Vegetables produced here during the dry season are either consumed by the people or sold for income. This explains the high demand that is often imposed on the dam during the long dry season. At this period of time, access to water for irrigation farming is critical to household survival. In other words, lack of access to irrigation facilities is a clear manifestation of poverty in many households in the community. The people of Binduri are certainly not oblivious of the limited and finite nature of dam, yet everybody wants to have access to the water. This in turn places undue pressure on the dam during the dry season, thus subjecting it to overuse and unsustainable management.

\subsection{Economic and Demographic Factors}

The people of Binduri depend largely on agriculture for their livelihood. As shown in Table 1, nearly every household in the community is engaged in some form of agricultural activity including crop cultivation and livestock production. These activities are largely carried out on subsistence basis.

Table 1. Dominant Occupation of Households

\begin{tabular}{|l|l|l|}
\hline Occupation & Frequency & Percentage \\
\hline Farming & 103 & 98.1 \\
\hline Trading & 2 & 1.9 \\
\hline Total & 105 & 100.0 \\
\hline
\end{tabular}

Source: Field Survey

A survey carried out on 105 respondents in the community as shown in Table 1 revealed that $98.1 \%$ of the respondents have farming as their dominant occupation. The concentration of 


\section{Macrothink}

the people in the field of farming is not a matter of choice but a matter of limited economic activities. As observed by Bromley (1992), one characteristic of life in a village economy is that it is critically dependent on local agriculture and natural resources. The local economy is not diversified and the people have limited options with respect to economic activities. Farming is thus the main basket from which the people draw their livelihood in the form of food and income. Dry season gardening in particular has become an important alternative livelihood scheme to the people of Binduri. "Three important goals of irrigated agriculture worldwide are a secure food supply to serve a growing world population, increased water conservation, and reduced environmental costs of agricultural production" Ward (2010: 321). The recognition of irrigation farming as an important livelihood scheme is reflected in the growing demand for water for dry season onion farming in the community. According to Saleth and Dinah (2006), water demand is increasing fast due to growing population, swelling food demand, expanding scale of economic activities, and broadening perspective of water in terms of its ecological and cultural roles. As Chen (2008: 83) notes "water withdrawals have increased more than twice as fast as population growth and currently one-third of the world's population live in countries that experience medium to high water stress". This scenario is not different from the situation in Binduri. As shown in Figure 3, my study reveals that there has been a consistent expansion of the irrigable area of the dam since 1995, when the dam was rehabilitated.

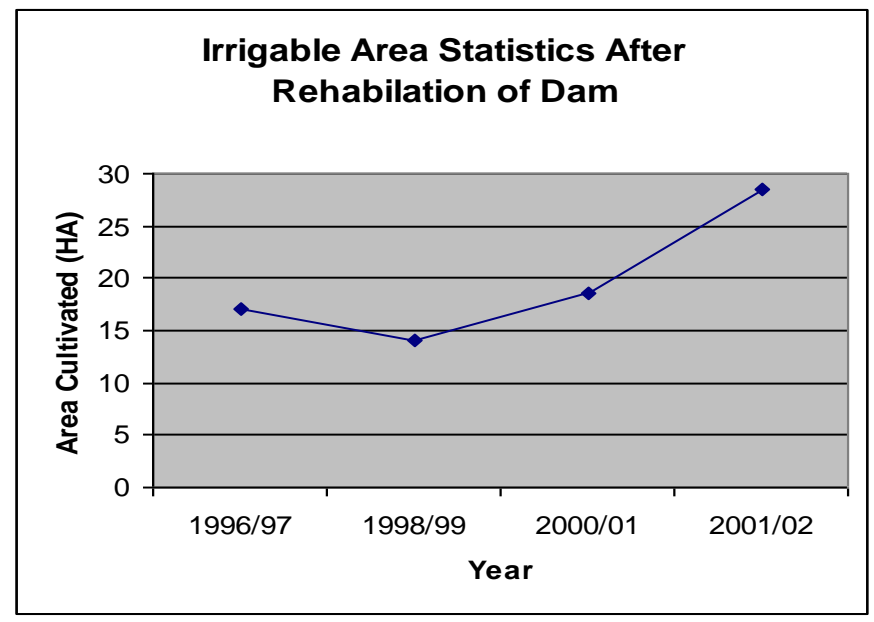

Figure 3. Irrigable Area Statistics after Rehabilitation of Dam

Source: MoFA Dam site Study Report (2004)

I found out that the expansion of the irrigable area was prompted by both economic and demographic factors. It was explained during a focus group discussion that there is good market for the onion produced in the community. The onions produced here are easily sold, and the income used to buy cereals to supplement the little harvest from rain-fed agriculture, and for other household commitments including the payment of children school fees and healthcare. 


\section{Ml Macrothink}

The population of the community is rapidly growing whiles the dam from which the livelihood of this growing population is largely drawn remains finite, if not declining. According to the 2000 National Population and Housing census reports, the Bawku Municipality of which the Binduri community belongs has a population density of 149 persons/sq. km.

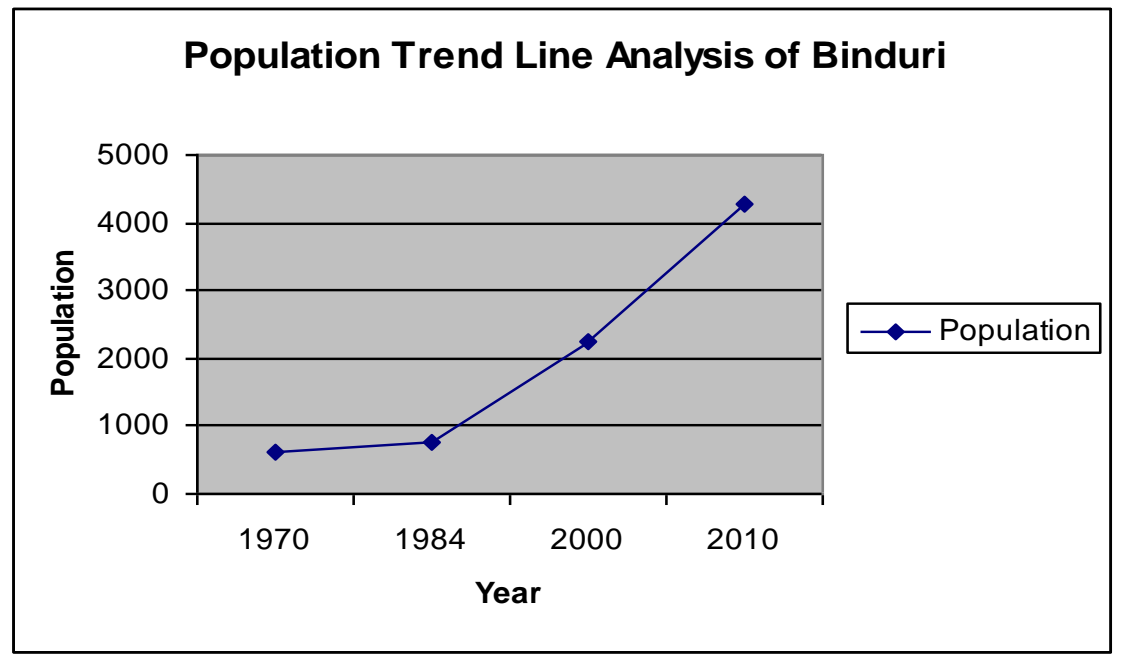

Figure 4. Population Trend Line Analysis (1970-2010)

Source: 2000 Population Census Reports.

As depicted in Figure 4, the population of Binduri has been rising rapidly since 1984.The rapid population growth being experienced in the community has implications for resource use and sustenance. As Cleaver and Schreiber (1994) point out, with the rate of population growth currently projected, water availability per capita will decline to half of its present levels in almost all Sub-Saharan Africa Countries within twenty years. This is no longer an imaginary situation, but a reality. The Binduri dam at the moment can only serve 458 irrigation farmers, representing barely $20 \%$ of the inhabitants of Binduri who are mainly farmers. The greatest challenge here is how to manage the high demand that this growing population places on the dam. In a community of this sort where nearly everybody is a farmer, and where rain-fed agriculture is increasingly becoming unreliable, irrigation facilities often come under pressure as it becomes difficult to regulate use. As Woodhouse et al (2000) note, institutional changes and the increasing demand for land and water generated by a rapidly growing population have had a profound impact on the dynamics of resource access. On his part, Williams (1998) notes that changing land use as a result of rapid population growth and declining rainfall has increased the pressure of production on common pool resources. "Humanity, both in numbers and in per capita exploitation of the Earth's resources is expanding with significant impact on the world's ecosystems and natural resources [...] Human activity is placing such strain on the natural functions of the Earth that the ability of the planet's ecosystem to sustain future generations can no longer be taken for granted" (Bologna, 2008: 338-341). The pressure on the community dam is obvious as less than $2 \%$ of the people in the Binduri community obtain their livelihood outside the agricultural sector. In the absence of effective mechanisms to effectively allocate use right to potential users, as 


\section{Ml Macrothink}

well as regulate use, the sustainability of the dam cannot be guaranteed.

This high demand for irrigable land and water places an enormous burden on the dam and the irrigation infrastructure. For instance, it was observed that in their quest for space to participate in the onion production, there is an emerging group of "squatter farmers" who remove slabs on the main canal to force water to flow in the opposite direction to their farms. This practice is more pronounced along the Right-Canal of the dam. Apart from causing damage to the irrigation infrastructure, this practice also puts a stress on the dam itself, as it causes considerable water leakage. This practice of diverting water from the main canals means that water has to be opened for longer hours before it can get to farmers at the end of the irrigable area. This practice often leads to the depletion of the dam water before the end of the onion farming season. This unsustainable use of the water thus places pressure on the dam and the irrigation infrastructure as a whole.

\subsection{Poor Catchment Area Management}

The struggle for space is as well affecting the management of the dam's catchment area which also has the potential of causing the siltation of the dam and reducing its water holding capacity. Though efforts aimed at protecting the catchment area of the dam such as tree planting, the growing of special grasses and bunding have been initiated in the area, the continuous farming activities at the catchment area of the dam is eroding efforts of its protection (see Akudugu, 2007). Attempts to convince farmers to relocate from these areas have not been successful. In separate focus group discussions in Asdyok and Asimiik Bulug, farmers in these areas argued that those places remain the only valleys accessible and suitable to them for rainy season farming and dry season gardening. They argued that most of them do not have access to the dam's irrigable land and as such have to find an alternative place for onion production so as to guarantee themselves some livelihood during the long dry season.

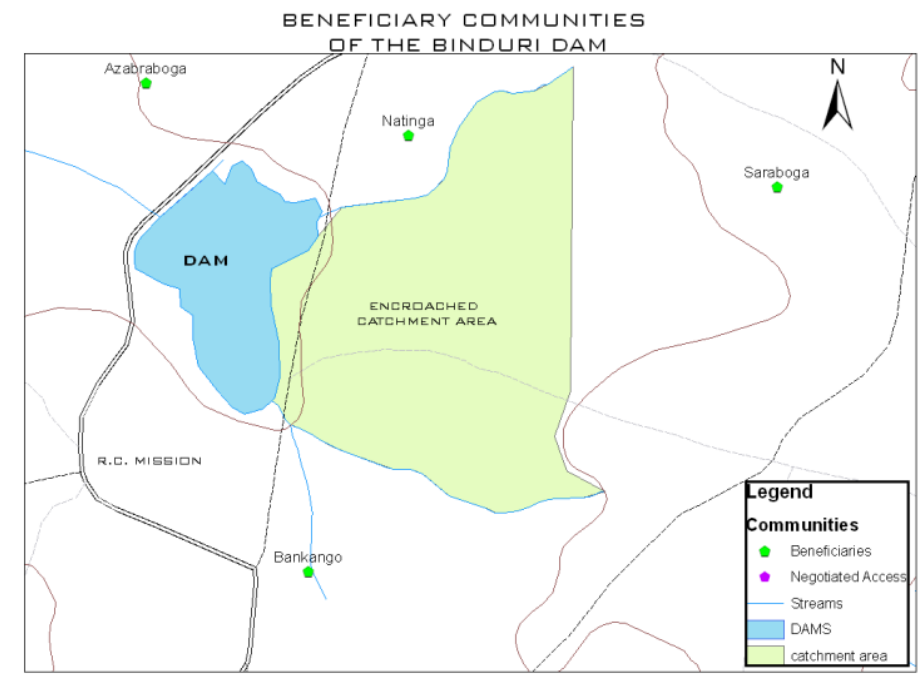

Figure 5. A sketch of the Dam's Catchment Area Source: Author's Construct

The encroached catchment area of the dam shown in Figure 5 is also the area where the two main streams that feed the dam (Asdyok and Asimiik Bulug) run through to the dam. The 
activities of farmers and residents and poor catchment area management practices contribute to the degradation of watersheds, (Chen, 2008). The encroached area shown in Figure 5 is intensively used for both rainy season farming and dry season irrigation farming. The dry season activities in particular are very detrimental to the dam. It entails an intensive tilling of the soil, the use of chemical fertilizer, the digging of shallow wells and the construction of mud fence walls around each individual unit or garden. As Chen (2008: 83) points out "the world's watersheds are under increasing pressure". The effect of farming activities to the dam especially during the rainy season is obvious; the mud walls get dissolved and are carried together with the heaps of sand from the shallow wells into the dam; resulting in its siltation.

Although the farmers have been educated and encouraged to plant economic trees such as mangoes, teak and cashew on the catchment area of the dam in place of crop farming and dry season gardening, they view this as a long term investment that may not yield tangible results in their life time. All they need is something to supplement the little they often obtain from their rainy season farming in order to sustain them for another season. It is in the light of this that Bullard (2011: 141) argues " ... the greatest challenge we face is not so much about how we understand sustainability, but rather how we understand development". The struggle for livelihood often stand against any effort aimed at bringing people together in the management of such a community resource. As noted by Moran (2006), when the interests of those using the resources differ, achieving a self-governing solution to a common resource may be quite challenging. The high level of inaction regarding the utilisation and management of resources led to the conclusion by Raghuram (2011: 145) that "sustainable development is rich in imagination and poor in historical action". It is obvious that in communities where the satisfaction of immediate needs is the pre-occupation of the people, sustainable management of common pool resources such as the Binduri community dam becomes elusive.

\subsection{Inadequate Technical Infrastructure}

Infrastructure is an essential component of irrigation schemes. In fact, irrigation is essentially a product of infrastructure. As Akudugu (2006) points out in his definition, "irrigation is a system that consists of a set of elements including water, land, established infrastructure like canals, tanks and pumping machines, as well as people, and institutions". In any irrigation system, infrastructure links the various elements together. For instance, it is through infrastructure that water is collected and transported to the crops or farms. The level and sophistication of irrigation infrastructure determines how much water can be collected and maintained overtime, the effectiveness of regulating water use, and the efficiency of water use among other things. The basic identifiable dam infrastructure associated with the Binduri community irrigation scheme includes the dam wall or embankment, the turn-over tap, and canals. The maintenance of these facilities constitutes an essential aspect of the community irrigation scheme management process, and the sustainability of the scheme. The study reveals that the community has been able to undertake a number of maintenance works on the dam's infrastructure with the use of local tools and knowledge.

However, despite these efforts, the management and/or sustainability of any irrigation system requires a high level of technical knowledge and technical tools for monitoring and regulating 
use as well as generating data for planning purposes that are currently lacking in the community. As Oakerson (1992) points out, the physical limits of a given resource established by nature or technology provide critical information for devising rules to maintain jointly beneficial use. Technical infrastructure does not only provide information for the use of community irrigation schemes, but also serves as a devise for monitoring and regulating the use of such resources. The people of Binduri still lack certain technical knowledge and technical infrastructure necessary for the effective monitoring and utilisation of the dam water. For instance, there is no authentic technical tool like a water gauge that indicates or monitors the level of water in the dam and its movement. Records showing the dam's water level, its rate of discharges and the level of sedimentation taking place on the dam cannot be obtained. The water level is currently been monitored with local knowledge and experience, which cannot generate any meaningful data for scientific analysis and action. Although many farmers in Ghana were able to rely on their years of experience in farming to predict the beginning and the end of the rainy season, they are unable to do so now because of the highly unpredictable nature of the rainfall in contemporary times (Gyampoh, et al 2008). Experience is important and could be complementary, but it cannot on its only translate into infrastructure or even scientific knowledge for the effective management of irrigation facilities, including water resources.

Besides, the existing irrigation infrastructure makes it difficult to effectively exclude potential farmers outside the scheme from using the water that runs through the canal. As stated earlier, farmers have been able to change the course of the water that runs through the canals by removing the slabs and forcing water to flow in the opposite direction of the canals. As Ramagundan (2009) notes, the issue of whose lands are irrigated first and whose are irrigated last has always been a contentious one. The existing infrastructure of the scheme has also not been effective in regulating the number of people who can access the water. As Oakerson (1992) points out, the degree of exclusion or access control attainable depends on both the physical nature of a resource or design of a facility, and available technology. The inadequate infrastructure in the Binduri irrigation scheme is thus making room for the misuse of water from the dam. Similarly, the absence of such technical devices like a water gauge makes it difficult for the estimation of the volume of water available for use. This affects planning in terms of water usage and management and can easily lead to the depletion of water in the dam.

\section{Conclusion}

The Binduri Irrigation Scheme, like others in the Bawku Municipality can be described as the life wire of the community, in terms of its contribution to household livelihood and income. As such, its sustenance is critical to the survival of the community. But the sustenance of this important community resource is currently challenged by both human and non-human factors. The human factors that threatens the sustainability of the scheme include the pressure exerted on it resulting from the high demand for dry season irrigation farming, weak self-regulating institutions, resulting in poor monitoring of use, regulation of use and enforcement of rules. The non-human factors that threaten the sustainability of the scheme include inadequate technical infrastructure, poor dam infrastructure and unfavourable rainfall. 


\section{Mll Macrothink}

Given its importance in the socio-economic life of the people, there is the need to take steps to check the threats on the scheme, so as to guarantee its sustainability and long-term viability. There is particularly the need to strengthen the technical infrastructure of the scheme, including the rehabilitation of canals and the provision of a gauge to monitor the level and movement of water in the dam reservoir. There is also the need to build the capacity of the officers of the Water Users Association to effectively enforce rules governing the use of the scheme, as well as monitor its use.

\section{References}

Akudugu, J. A. (2006). Community Management of Common Pool Resources: A study on the Utilisation of Water for Irrigation Farming in Binduri, Bawku Municipality. MSc. Thesis submitted to the Kwame Nkrumah University of Science and Technology, Ghana

Akudugu, J. A. (2007). The Role of User Organisations in the Management of Smallholder Irrigation Schemes: The Case of the Binduri Water User Association in the Bawku Municipality. Ghana Journal of Development Studies, 4(2), 59-74.

Akudugu J. A. (2008). Determining Access to Common Pool Resources. A Study on the Use of a Community Dam for Irrigation Farming in Binduri, Bawku Municipality. Ghana Journal of Development Studies, 5(2). 27-39.

Bawku Municipal Assembly. (2002). District Medium Term Development Plan. Unpublished.

Bologna, G. (2008). Global Environmental Change and the Challenge of Sustainability. Development, 51(3), 338-343. http://dx.doi.org/10.1057/dev.2008.26

Bromley D. W. (1992). Making the Commons Work. Theory, Practice and Policy. San Francisco. Institute for Contemporary Studies.

Bullard, N. (2011). It's too late for Sustainability. What we need is System Change. Development, 54(2), 141-142. http://dx.doi.org/10.1057/dev.2011.29

Chen, S. (2008). From Community-based Management to Transboundary Watershed Governance. $\quad$ Development, $\quad 5(1), \quad 83-88$. http://dx.doi.org/10.1057/palgrave.development.1100445

Gyampoh, B. A., Idinoba, M., \& Amisah, S. (2008). Water Scarcity under a changing Climate in Ghana: Options for Livelihood Adaptation. Development, 51(3). 415-417. http://dx.doi.org/10.1057/dev.2008.46

Haughton, G., \& Counsell, D. (2004). Regions, Spatial Strategies and Sustainable Development. Oxon. Routledge.

Lorenzen, S., \& Lorenzen, R. P. (2008). Institutionalising the Informal: Irrigation and Government Intervention in Bali. Development, 5(1), 77-82. http://dx.doi.org/10.1057/palgrave.development.1100441

Meteorological Service Department. (2006). Rainfall Figures for Binduri. Bolgatanga. Unpublished. 
Ministry of Food and Agriculture. (2004). Report on 2002/2003 Dry Season Vegetable Cropping at LACOSCREP Dam Sites. Unpublished.

Njoh, A. J. (2011). Citizen Participation and Sustainability: Lessons from Cameroon. Development, 54(3), 376-383. http://dx.doi.org/10.1057/dev.2011.55

Oakerson, R. J. (1992). Analysing the Commons. A Framework. In Bromley D. W (ed): Making the Commons Work. Theory, Practice and Policy. San Francisco. Institute for Contemporary Studies.

Ostrom, E. (1990). Governing the Commons: The Evolution of Institutions for Collective Action. New York. Cambridge University Press.

Ostrom, E., Garner, R., \& Walker, J. (1994). Rules, Games and Common-Pool Resources. Michigan. University of Michigan.

Portney, P. R. (1982), (ed.): Current Issues in Natural Resource Policy. Washington D.C. Resources for the Future Inc.

Raghuram, S. (2011). Sustainable Development: The citizen's predicament. Development, 54(2), 143-146. http://dx.doi.org/10.1057/dev.2011.30

Ramagundan, R. (2009). Complexities in Natural-Resource Management: Irrigation Infrastructure in Bihar. Development in Practice, 19(1), 16-27. http://dx.doi.org/10.1080/09614520802576344.

Seini, W. A. (2002). Agricultural Growth and Competiveness under Policy Reforms in Ghana. Technical Publication No. 61. ISSER, Accra.

Shepherd, A. (1998). Sustainable Rural Development. London. Macmillan Press Ltd.

Ward, F. A. (2010). Financing Irrigation Water Management and Infrastructure: A review. International Journal of Water Resources Development, 26(3), 321-349. http://dx.doi/10.1080/07900627.2010.489308.

Williams, T. O. (1998). Multiple Uses of Common Resources in Semi-Arid West Africa: A survey of existing practices and options for sustainable resource management. London. Overseas Development Institute.

Woodhouse, P., Bernstein, H., \& Hulme, D. (2000). African Enclosures? The Dynamics of Wetlands in Drylands. Oxford. James Currey Limited.

\section{Copyright Disclaimer}

Copyright reserved by the author(s).

This article is an open-access article distributed under the terms and conditions of the Creative Commons Attribution license (http://creativecommons.org/licenses/by/3.0/). 